\title{
SYSTEMIC LUPUS ERYTHEMATOUS: SPECIFIC MUCOCUTANEOUS MANIFESTATIONS \& SEROLOGICAL MARKERS AS KEY DIAGNOSTIC TOOLS: A SERIES OF 3 CASE REPORTS
}

\author{
Priyankar Singh ${ }^{1}$,Kranti C. Jayakar ${ }^{2}$, Richa Thakur ${ }^{3}$,Arbind K. Sharma ${ }^{4}$, Krishna Biswas $^{5}$ \\ ${ }^{1}$ Senior Resident, Department of Dentistry, Indira Gandhi Institute of Medical Sciences, Patna. \\ ${ }^{2}$ Assistant Professor, Department of Dermatology, Indira Gandhi Institute of Medical Sciences, Patna. \\ ${ }^{3}$ Senior Resident, Department of Dermatology, Indira Gandhi Institute of Medical Sciences, Patna. \\ ${ }^{4}$ Professor and HOD, Department of Dentistry, Indira Gandhi Institute of Medical Sciences, Patna. \\ 5 Post Graduate Student, Department of Endodontics, Tamilnadu Government Dental College.
}

\section{ABSTRACT}

\section{BACKGROUND}

Systemic Lupus Erythematous (SLE) is an autoimmune disorder with a multi-system clinical presentation. Due to its less prevalence, its diagnosis still confuses the health care providers. It occurs most commonly in young women and apart from its clinical presentation, many serological markers and histological findings can aid as important tools in its confirmed diagnosis. Some marked oral manifestations of this systemic disease and immunological presentation of increased antinuclear antibodies, anti-DS-DNA and IgE along with a blood picture of pancytopenia hints a lot more about this rare autoimmune disease. Management of SLE is a complex issue and starts with patient education, counselling and assurance about the relapsing, remission pattern and unpredictable course of the disease. The aim of SLE management is based on prevention; reversal of inflammation, maintaining states of remission and alleviation of symptoms.

\section{KEYWORDS}

Systemic Lupus Erythematous, Oral Manifestations, Serological Markers, Diagnostic Tools.

HOW TO CITE THIS ARTICLE: Singh P, Jayakar KC, Thakur R, et al. Systemic lupus erythematous: specific mucocutaneous manifestations and serological markers as key diagnostic tools: a series of 3 case reports. J Evolution Med Dent Sci 2016;5(2):

165-170, DOI: $10.14260 /$ jemds/2016/38

\section{INTRODUCTION}

Systemic Lupus Erythematosus (SLE) is a heterogeneous prototypic autoimmune disorder with a broad spectrum of multiorgan clinical presentation, and significant morbidity and mortality. ${ }^{1}$ It is characterized by antinuclear antibodies and complement deposition and affects women more than men with a reported female to male ratio of $10: 1.2,3$ and prevalence of $1: 1000.4$

SLE can affect the joints, skin, mucosa, muscles, brain, lungs, kidneys, digestive tract, heart, blood vessels, lymphatics and is diagnosed considering the criteria set by the American College of Rheumatology (ACR). 5

The classic facial butterfly rash occurs only in about onethird of persons and oral or nasopharyngeal manifestations occurs in up to $25 \%$ of patients which presents itself as discoid, erythematous or ulcerative lesions and may resemble lichen planus or leukoplakia. Immunocompromised system also elevates the risk of periodontal disease. ${ }^{6}$

\section{CASE REPORT}

\section{Case \# 1}

A 39-year-old female reported to the Department of Dentistry with complaints of fever, difficulty in mouth opening, swallowing, burning sensation all over mouth with ulcerations and rashes on face with severe itching since last 3 months.

Financial or Other, Competing Interest: None.

Submission 18-12-2015, Peer Review 19-12-2015,

Acceptance 02-01-2016, Published 07-01-2016.

Corresponding Author:

Dr. Priyankar Singh,

Senior Resident,

Department of Dentistry,

Indira Gandhi Institute of Medical Sciences,

Patna-800014.

Bihar.

E-mail: spriyankar@yahoo.co.in

DOI:10.14260/jemds $/ 2016 / 38$
On extra oral examination, entire face and neck showed discoid cutaneous rash with erythema with mild alopecia in anterior scalp hairline. Classical "Butterfly" rash-mask shaped flat erythema was noted over the malar eminences, bridge of nose and typically sparing the nasolabial folds, which aggravated on sun exposure [Figure 1a].

Reduced mouth opening with slivery crusting on both lips was noted with ulcerations at lip commissure bilaterally [Figure 1b]. Intra orally, generalized palatal erythema with typical desquamative gingivitis was observed. Buccal mucosa was erythematous and multiple sites of tender oral ulceration were seen with burning sensation, which bled on wiping with gauze [Figure 1c].

All molars were carious with grade II mobility. On referral to department of dermatology, generalized cutaneous rashes with petechiae were noted all over the body especially at extremities and back [Figure 1d]. With patient's consent routine blood investigations was done which showed pancytopenia and marked increased in titer of anti-DS (double stranded)-DNA, ANA (Anti-nuclear antibodies) and IgE. Creactive protein was found to be negative and rheumatoid factor was positive.

We did a scrap cytology and the histological picture revealed presence of hyperkeratosis, sub-epithelial and perivascular infiltrates and disturbed keratinization with cellular atypia and basal cell degeneration. Following an interdepartmental discussion and considering the ACR criteria, diagnosis of SLE was made and supportive and symptomatic care was started. Oral topical steroid application (TRIAMCINOLONE 0.1\%) with anesthetic gel was started and patient was counselled for protection from sun and continuous maintenance of oral hygiene. Systemically, patient was put on Tab hydroxychloroquine $200 \mathrm{mg}$ BD, Tab fexofenadine $180 \mathrm{mg}$ BD along with tapering dose of Tab deflazacort 60mg OD which was later changed to azathioprine. Topical application of 
avobenzone was also advised as sunscreen. Patient was followed every two weeks and overall improvement in condition was noticed.

\section{Case \# 2}

A 29-year-old female patient reported to Department of Dentistry, with complaints of painful ulcerations on lip and difficulty in mouth opening with burning sensation on eating since 5 months. She also complained of intermittent fever with severe joint pains since last 15 days.

Extra oral signs showed mild malar rash with lip crusts and bleeding spots. She also had complete non-scarring alopecia of scalp, eyebrows and axial region bilaterally [Figure 2a]. Mouth opening was difficult but normal, due to painful lip ulcerations [Figure 2b].

Intraorally buccal mucosa was blanched with small discoid ulcers opposite to occlusal plane with no signs of any carious tooth [Figure 2c]. A very small palatal ulcer was seen with erythematous halo around it. Generalized small petechiae were seen on hands and more on both legs with history of itching more on sun exposure [Figure 2d]. Considering systemic features patient was referred to department of Dermatology and following ACR criteria SLE was diagnosed.

Blood picture classically showed a 10 fold increase in anti-DS-DNA, ANA (Anti-nuclear antibodies) and IgE from its normal value but with a marked decrease in $\mathrm{C}_{3}$ level. Complete blood count showed normocytic-normochromic anemia with thrombocytopenia and lymphocytopenia.

On scrap cytology the histopathological picture showed marked hyperkeratosis and acanthosis with basal cell degeneration and thickening of basement membrane zone. After patient consent and counselling same management protocol was followed as with above case and patient showed improvement with every followup.

\section{Case \# 3}

A 62-year-old female patient reported to department of Dermatology, with chief complain of facial and body rashes with severe itching and burning sensation in mouth since last 6 months and frequent fever with joint pain since last 3 months.

Patient was a known diabetic and hypertensive with history of nephritic range proteinuria since last 2 years. She also presented with a vague drug allergy history and was unaware of the drugs she was allergic to. On general examination skin rashes and discoid lesions, were seen mainly on face and both extremities, with history of aggravation in sun exposure [Figure 3a \& 3d].

The classic malar rash was significant but with mainly brown pigmentation. She also had uveitis in the right eye since last 1 year. On referral to dental department, mouth opening was seen normal [Figure $3 \mathrm{~b}$ ], with blanched buccal mucosa and mild erythema on hard palate and faucial pillars [Figure 3c].

Multiple teeth were with grade II mobility and carious mandibular molars. Routine blood picture showed reduced hemoglobin level with thrombocytopenia and normal lymphocyte count. Increase in anti-DS-DNA, ANA (Antinuclear antibodies) and IgE were significant in this patient too with a mild reduction in $\mathrm{C}_{3}$ a level. On scrap cytology the histological picture revealed hyperkeratosis, basal layer degeneration, thickening of basement membrane along with deep perivascular infiltrate.

After a thorough discussion and following guidelines of ACR, SLE was diagnosed and same management protocol was followed for oral and systemic lesions after patient's consent. She was also referred to department of ophthalmology for management of uveitis. Patient reported at regular followup with marked improvement in overall condition.

\section{DISCUSSION}

SLE can have a vicious clinical histological and immunological course, and is probably the most challenging of all autoimmune rheumatic disorders to control. Our study goes hand in hand with various other studies to state the importance of marked oral presentation in SLE. ${ }^{7}$

A myriad of features appear in oral cavity, may be secondary to epithelial atrophy and subsequent scarring, including discoid lesions, cheilitis, white patches like lichen planus and erythematous buccal mucosa which were consistent with our cases reported here. ${ }^{8}$

Our study also seems consistent with few studies depicting specific immunological changes as marked increase in anti-DS-DNA, ANA and IgE, which could be a key diagnostic tool in confirming the diagnosis of SLE. ${ }^{9}$ Tissue damage is caused by platelets and neutrophils and the cascade is completed by involvement of complements C $3 \mathrm{a}, \mathrm{C} 4 \mathrm{a}$ and $\mathrm{C} 5 \mathrm{a} .{ }^{10}$

Histopathological analysis showed homogeneous features with hyperkeratosis and acanthosis as significant observations in all cases, which may be possibly produced as a response of the epithelia to the chronic aggression.

Basal stratum degeneration and thickening of the basal membrane were also seen as congruent with previous studies. ${ }^{11} \mathrm{~A}$ tabulated description of all the findings of our cases is depicted in Table 1. Management of SLE is a complex issue and starts with patient education, counselling and assurance about the relapsing, remission pattern and unpredictable course of the disease.

\section{REFERENCES}

1. Manson JJ, Rahman A. Systemic lupus erythematosus. Orphanet J Rare Dis. 2006;1:6.

2. Maidhof W, Hilas O. Lupus: an overview of the disease and management options. Pharmacy and Therapeutics. 2012 April;37(4):240-246, 249.

3. Sultan SM, Ioannour Y, Isenberg A. A review of gastrointestinal manifestations of systemic lupus erythematosus. Rheumatology. 1999;38:917-32.

4. American College of Rheumatology Ad Hoc Committee on Systemic Lupus Erythematosus Guidelines. Guidelines for referral and management of SLE in adults. Arthritis Rheumatol. 1999;42(9):1785-1796.

5. McCauliffe DP. Cutaneous lupus erythematosus. Semin Cutan Med Surg 2001;20:14-26.

6. Estes D, Christian CL. The natural history of systemic lupus erythematosus by prospective analysis. Medicine (Baltimore) 1971;50(2):85-95.

7. López-Labady J, Villarroel-Dorrego M, González N, et al. Oral manifestations of systemic and cutaneous lupus erythematosus in a Venezuelan population. J Oral Pathol Med. 2007;36:524-7. 
8. Orteu CH, Buchanan JA, Hutchison I, et al. Systemic lupus erythematous presenting with oral mucosal lesions: easily missed? Br J Dermatol 2001;144(6):1219-1223.

9. Jonsson R, Svalander C, Nyberg G. Immune deposits in oral mucosa, skin and kidney in patients with systemic lupus erythematosus. Clin Exp Rheumatol 1986;4:231-6.
10. Cervera R, Khamashta MA, Font J, Sebastiani GD, Gil A, Lavilla $\mathrm{P}$ and others. Systemic lupus erythematosus: clinical and immunologic patterns of disease expression in a cohort of 1,000 patients. The European Working Party and Systemic Lupus Erythematosus. Medicine (Baltimore) 1993;72(2):113-24.

11. Reibel J, Schiodt M. Immunohistochemical studies on colloid bodies (civatte bodies) in oral lesions of discoid lupus erythematosus. Scand J Dent Res 1986;94:536-44.

\begin{tabular}{|c|c|c|c|c|c|c|c|}
\hline Case & $\begin{array}{l}\text { Age } \\
/ \text { Sex }\end{array}$ & $\begin{array}{l}\text { Type } \\
\text { of } \\
\text { LE }\end{array}$ & $\begin{array}{c}\text { Oral } \\
\text { Lesions }\end{array}$ & $\begin{array}{c}\text { Cutaneous/ } \\
\text { Systemic } \\
\text { Lesions }\end{array}$ & $\begin{array}{c}\text { Histopathological } \\
\text { Analysis }\end{array}$ & $\begin{array}{c}\text { Serological } \\
\text { Analysis }\end{array}$ & $\begin{array}{c}\text { ACR } \\
\text { Criteria } \\
\text { Fulfilled }\end{array}$ \\
\hline 1. & $39 / F$ & SLE & $\begin{array}{l}\text { 1. Generalized } \\
\text { palatal erythema } \\
\text { 2. Desquamative } \\
\text { gingivitis } \\
\text { 3.Erythematous } \\
\text { buccal mucosa } \\
\text { 4. Ulcer on buccal } \\
\text { mucosa with } \\
\text { bleeding tendency } \\
\text { 5. Silvery crusting } \\
\text { on both lips } \\
\text { 6. Reduced mouth } \\
\text { opening }\end{array}$ & $\begin{array}{l}\text { 1. Discoid cutaneous } \\
\text { rash } \\
\text { 2. Butterfly malar rash } \\
\text { 3.Alopecia of anterior } \\
\text { scalp hairline } \\
\text { 4. Generalized } \\
\text { petechiae. } \\
\text { 5. Photosensitivity } \\
\text { 6. Fever with joint pain }\end{array}$ & $\begin{array}{l}\text { 1. Hyperkeratosis } \\
\text { 2. Sub-epithelial and } \\
\text { perivascular } \\
\text { infiltrates. } \\
\text { 3. Cellular atypia } \\
\text { 4. Basal cell } \\
\text { degeneration } \\
\text { 5. Disturbed } \\
\text { keratinization }\end{array}$ & $\begin{array}{l}\text { 1. Pancytopenia } \\
\text { 2. Increased } \\
\text { titer of Anti DS - } \\
\text { DNA } \\
\text { 3. Increased } \\
\text { titer of ANA } \\
\text { 4. Increased } \\
\text { titer of IgE } \\
\text { 5. Rheumatoid } \\
\text { factor positive } \\
\text { 6. C- reactive } \\
\text { protein } \\
\text { negative }\end{array}$ & YES \\
\hline 2. & $29 / F$ & SLE & $\begin{array}{l}\text { 1.Blanched buccal } \\
\text { mucosa } \\
\text { 2. Discoid ulcers } \\
\text { opposite to occlusal } \\
\text { plane } \\
\text { 3. Palatal ulcer with } \\
\text { erythematous halo } \\
\text { 4. Silvery crusting } \\
\text { on both lips } \\
\text { 5. Reduced mouth } \\
\text { opening }\end{array}$ & $\begin{array}{l}\text { 1. Complete non- } \\
\text { scarring alopecia of } \\
\text { scalp, eyebrows and } \\
\text { axillary hairs } \\
\text { 2. Faint malar rash } \\
\text { 3. Generalized body } \\
\text { petechiae. } \\
\text { 4. Photosensitivity } \\
\text { 5. Fever with joint pain }\end{array}$ & $\begin{array}{l}\text { 1. Hyperkeratosis } \\
\text { 2. Cellular atypia } \\
\text { 3. Acanthosis } \\
\text { 4. Basal cell } \\
\text { degeneration } \\
\text { 5. Basal membrane } \\
\text { thickening }\end{array}$ & $\begin{array}{l}\text { 1. Pancytopenia } \\
\text { 2. Increased } \\
\text { titer of Anti DS - } \\
\text { DNA } \\
\text { 3. Increased } \\
\text { titer of ANA } \\
\text { 4. Increased } \\
\text { titer of IgE } \\
\text { 5. Rheumatoid } \\
\text { factor positive } \\
\text { 6. C3alevel } \\
\text { decreased }\end{array}$ & YES \\
\hline 3. & $69 / F$ & SLE & $\begin{array}{l}\text { 1.Blanched buccal } \\
\text { mucosa } \\
\text { 2. Palatal erythema } \\
\text { 3. Normal mouth } \\
\text { opening } \\
\text { 4. Faucial pillars } \\
\text { erythema } \\
\text { 5. Generalized } \\
\text { periodontitis with } \\
\text { mobile teeth }\end{array}$ & $\begin{array}{c}\text { 1. Butterfly malar rash } \\
\text { 2. Discoid cutaneous } \\
\text { rash } \\
\text { 3. Generalized body } \\
\text { petechiae. } \\
\text { 4. Photosensitivity } \\
\text { 5. Uveitis of right eye } \\
\text { 6. Nephritic range } \\
\text { proteinuria }\end{array}$ & $\begin{array}{l}\text { 1. Hyperkeratosis } \\
\text { 2. Deep perivascular } \\
\text { infiltrates. } \\
\text { 3. Cellular atypia } \\
\text { 4. Basal cell } \\
\text { degeneration } \\
\text { 5. Basal membrane } \\
\text { thickening }\end{array}$ & $\begin{array}{l}\text { 1. Pancytopenia } \\
\text { 2. Increased } \\
\text { titer of Anti DS - } \\
\text { DNA } \\
\text { 3. Increased } \\
\text { titer of ANA } \\
\text { 4. Increased } \\
\text { titer of IgE } \\
\text { 5. Rheumatoid } \\
\text { factor positive } \\
\text { 6. C Calevel } \\
\text { decreased }\end{array}$ & YES \\
\hline
\end{tabular}



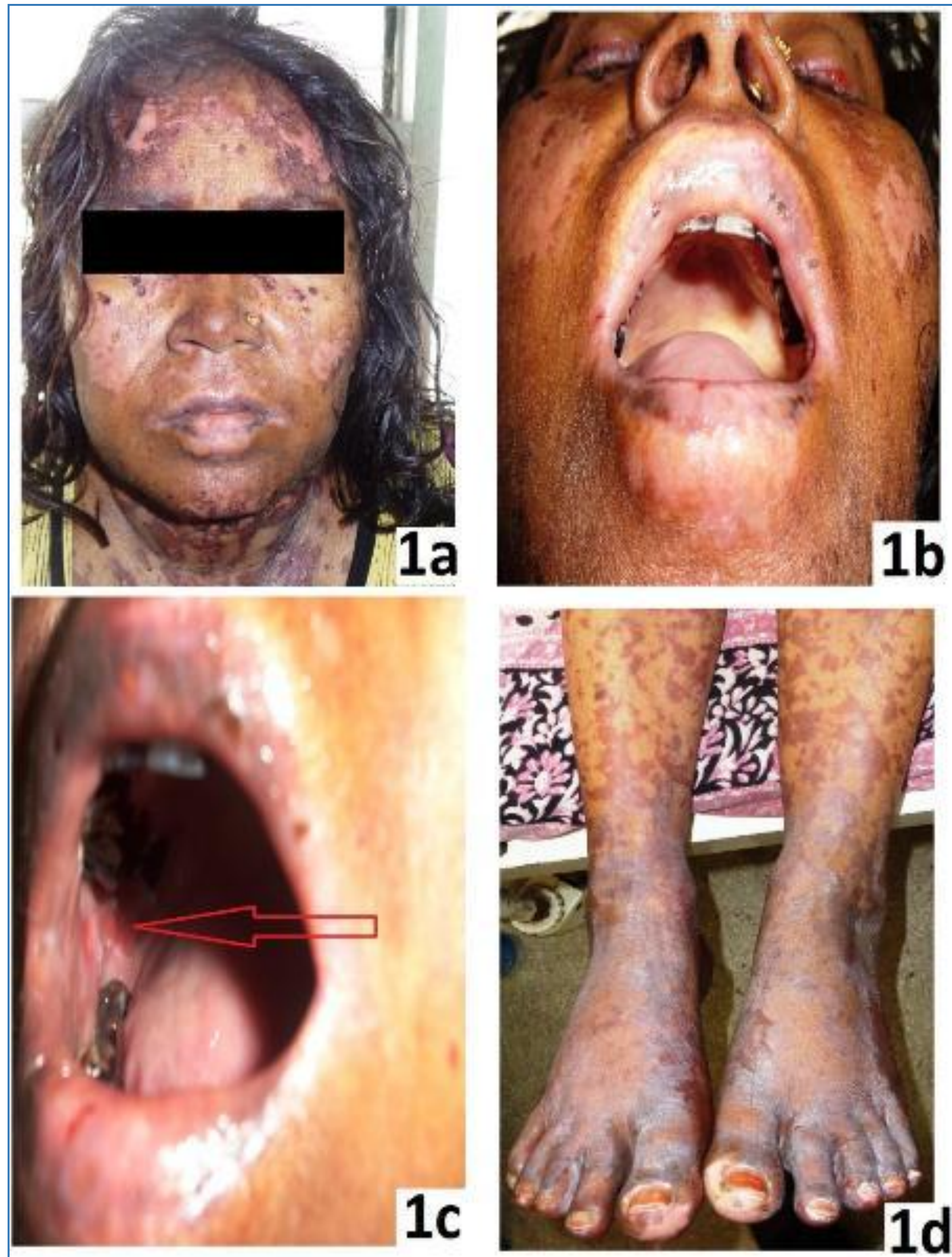

Fig. 1a) Extraoral manifestations with butterfly malar rash and facial rashes.

1b) Reduced mouth opening and lip crustations.

1c) Intraoral erythematous buccal mucosa with ulceration.

1d) Cutaneous rashes with petechiae at extremities 


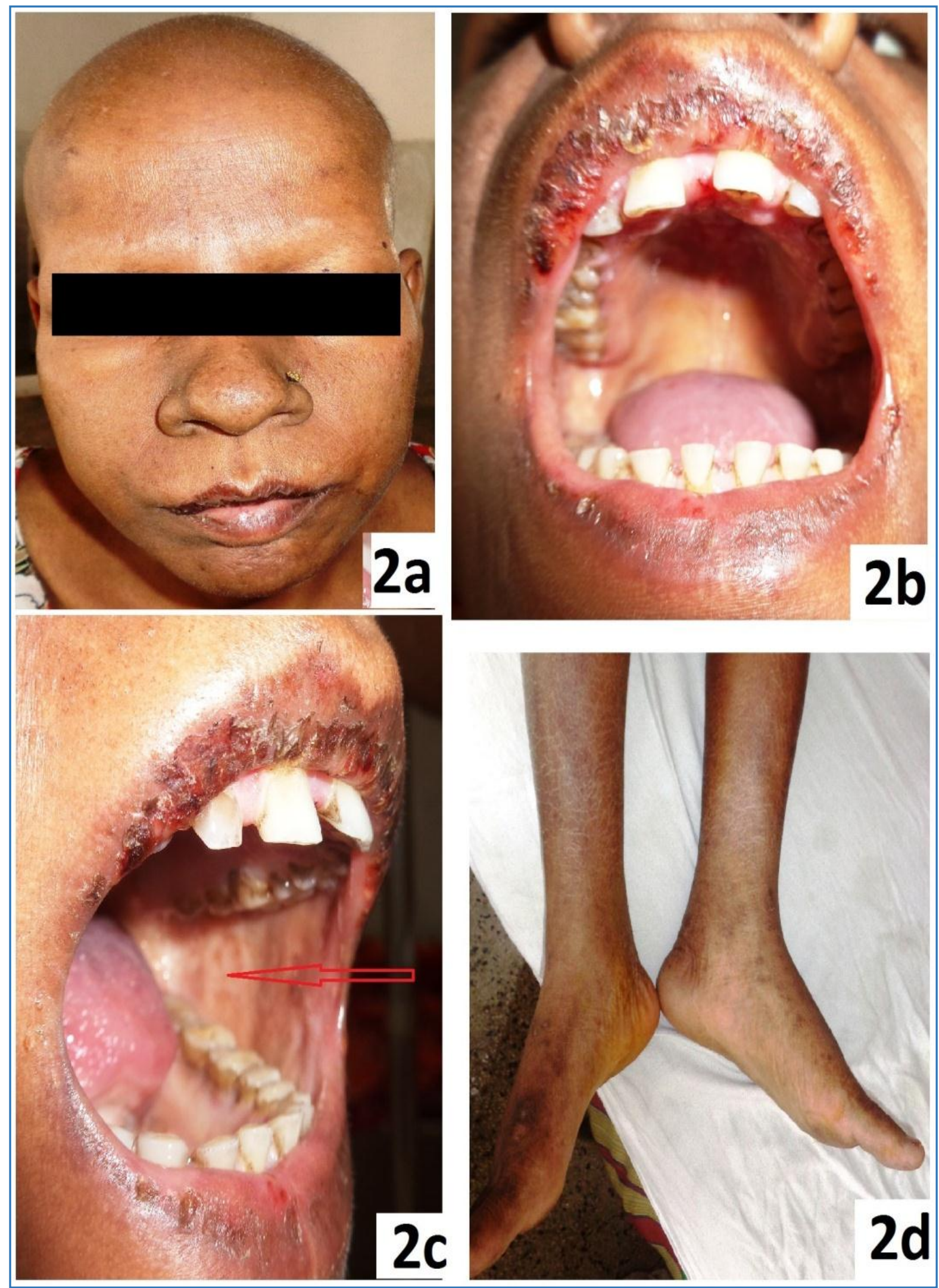

Fig. 2a) Extraoral manifestations with complete alopecia and mild facial rashes.

2b) Difficulty in mouth opening and lip crustations.

2c) Intraoral blanched buccal mucosa with ulceration.

2d) Cutaneous rashes with petechiae at extremities 


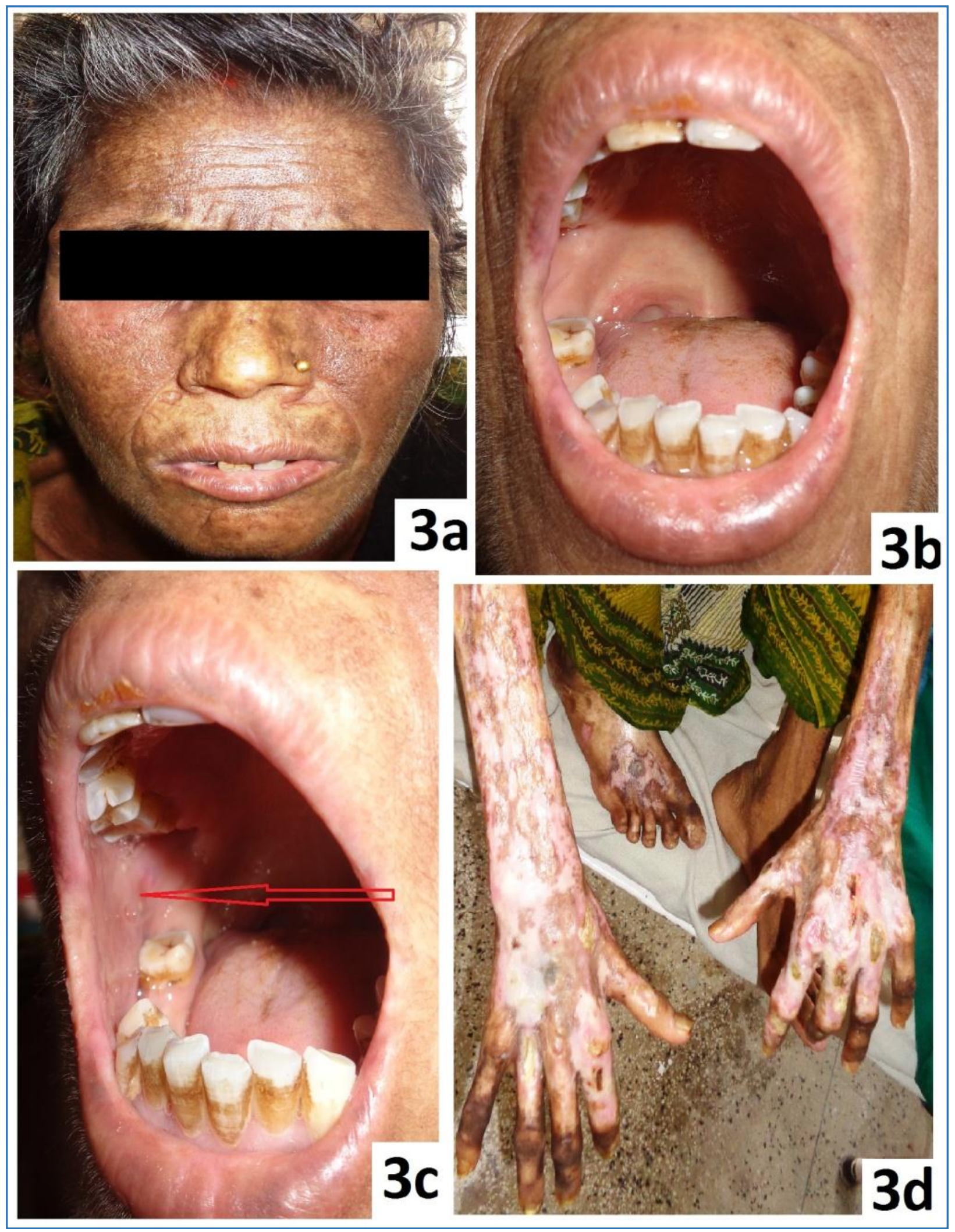

Fig. 3a) Extraoral manifestations with butterfly malar rash and severe facial rashes. 3b) Normal mouth opening and mild lip crustations.

3c) Intraoral blanched buccal mucosa with small pit ulceration.

3d) Cutaneous rashes with petechiae at extremities 